\begin{tabular}{c} 
Volume and Issues Obtainable at Center for Sustainability Research and Consultancy \\
Journal of Business and Social Review in Emerging Economies \\
ISSN: 2519-089X (E): 2519-0326 \\
Volume 6: No. 1, March 2020 \\
CSRᄃ \\
Journal homepage: www.publishing.globalcsrc.org/jbsee \\
\hline
\end{tabular}

\title{
Learning Styles and Employee Creative Behavior; An Exploration Through Cognitive Styles
}

${ }^{1}$ Saima Yasmeen, ${ }^{2}$ Iram Batool, ${ }^{3}$ Ruqia Safdar Bajwa

${ }^{1}$ MPhil Scholar, Institiute of Southern Punjab, Multan, Pakistan

${ }^{2}$ Assistant Professor Dept. of Applied Psychology, Bahauddin Zakaria University Multan, Pakistan: i.batool@bzu.edu.pk

${ }^{3}$ Lecturer, Dept. of Applied Psychology, Bahauddin Zakaria University, Multan, Pkistan: ruqiasafdar@bzu.edu.pk

\begin{tabular}{l} 
ARTICLE DETAILS \\
\hline History \\
Revised format: February 2020 \\
Available Online: March 2020
\end{tabular}

Keywords

Cognitive Styles, Learning

Styles, Employee Creativity

\section{JEL Classification:}

D8, J5

\begin{abstract}
Cognitive styles are the thinking patterns that greatly influence our everyday activities. Individuals may adopt particular learning styles to the way they want to perform. Creativity is a key feature and a great necessity of any organization in this competitive era. There is a need to explore what types of learning and cognitive styles will be helpful for the personnel to be creative. The main purpose was to find out the mediating role of cognitive styles in relationship of learning styles and employee creativity. It was also aimed to explore these variables. Descriptive research design was used and data was collected from 450 banks, insurance and telecommunication sectors (public and private) employees through convenient sampling. Cognitive style inventory (CS; Ancona, Kochan, Scully, Van Maanen, and Westney, 1997), Learning Style Questionnaire (LS; O Brein 1985), and Employee Creativity Questionnaire (EC; Tierney et al. in 1999) were used. Descriptive statistics, reliability of scales, t-test and One way ANOVA, was calculated by using SPSS. To check moderation, Partial least square structural Equation modeling (smart PLS) was used. Cognitive styles had significant moderating effect on learning styles and employee creativity. Limitations and suggestions are discussed.
\end{abstract}

(C) 2020 The authors, under a Creative Commons AttributionNonCommercial 4.0

Corresponding author's email address: $\underline{\text { i.batool@bzu.edu.pk }}$

Recommended citation: Yasmeen, S., Batool, I., Bajwa, S. \& Saqib, M., (2020). Does Learning Styles and Employee Creative Behavior; An Exploration Through Cognitive Styles. Journal of Business and Social Review in Emerging Economies, 6(1), 43-54

DOI: $10.26710 /$ jbsee.v6i1.1024

\section{Introduction}

Cognitive style is an important area discussed in many disciplines in different manners. Initially, it was a part of Jungian and Piagetian psychology but now cognitive styles were used in various fields .All of such discipline have a common purpose to study cognitive styles that how an individual process and store information and better adjusted to the diverse ranges of population (Palmaquist et al, 2000).Cognition 
involves different higher mental process which includes awareness, perception, reasoning and judgment. Carl Jung describes his psychological types (Jung, 1923) which comprises of three personality facets. First facet involves an attitude, which ranges from extroversion to introversion Second facet involves perception of stimulus which ranges from intuitive (meaning oriented) to sensing (detail oriented) The final facet involves three dimension judgment, thinking and feeling. Judgment involves decision, thinking involves logical patterns and reasoning and feeling involves value-based judgments. Goldstein et al, (1978) define cognitive styles as a mediating relationship between stimulus and response. Individual to organize environment they used this term. Cognitive styles were used to transfer information and stimulus is used to interpret that information into meaningful schema. So cognitive styles cover all the aspects of personality and cognition so we might say that cognitive styles is a relationship between intelligence and personality (Sternberg \& Grigorenko, 1997; Ridding \& Cheema, 1991). Mostly learning styles and cognitive styles terminology are treated in same manner (Pask, 1976) while some researchers disagree with that and states that learning style is a dominant strategy used by a person while cognitive style is a permanent characteristics of a person. (Ridding \& Cheema, 1991; Roberts \& Newton, 200). Cognitive style is a psychological dimension, which shows that individual have a consistent pattern of higher mental functioning. Higher mental functioning involves acquiring and process information. (Ausburn \& Ausburn, 1978).

\subsection{Learning Styles}

A preferred way to used one's abilities is known as learning style (Sternberg, 1994). Learning style is one of the key notions relating individual differences in learning. Different authentic learning has been widely used to improve problem solving skills and achievements approved by many studies (Hwang et al., 2010; Chen \& Lin, 2016). There are many individuals who use different types of learning styles and these learning styles are different in their nature, habits and in terms of the preference way to gather, store and retrieve new information and skills and it is modified and changed with circumstances (Reid, 1995). Learning styles are bipolar in nature. It exhibits two extreme with a wide variety of range. When a learner falls on these ranges or extremes, its value will become neutral because each extreme have its own pros and cons (Dörnyei, 2005). So we might say that learning styles can be extended and vary from situation to situation as the behavior changes (Reid, 1987; Oxford, 2011). Sternberg and Grigorenko in their study have outline three main motives to study learning styles. It provides relationship between cognition and personality. Therefore, learning styles are the ways that differ in the ability to accumulate assemble and assimilate information. Furthermore, our learning style allows us to gather and use specific knowledge in a useful manner. Many researchers point out that there are three basic types of learning styles. It depends on person one uses a single either style or used a combination of different styles. Learning styles should be identified at an early age so that the educational process can be maximizing by adopting that particular learning style (Ldpride.net, 2008).Lucas and Corpuz (2007) defined learning styles as a way individual can process information, think, remember and solve a particular problem. There are two perspectives of learning-thinking styles are sensory preferences and global analytical continuum. The sensory preferences defines as the person is attracted towards sensory input and remained dominant in the below mentioned types. Visual learners are those person who become position holders, great sense of humor and always tried to remain in the front row, love to be loved and love to manage events are visual learners.(Ldpride.net, 2008). While auditory learners have good listening power and they efficiently absorb new information by means of sounds, teachings, music, etc. these learners can record lecturers so that they will help them later in their studies. Auditory learners usually read aloud to retain information. Auditory learners perform better on oral presentations than written materials (Ldpride.net, 2008). Kinesthetic learners are the individuals who can learn best by touching, moving and acting out are called kinesthetic learners. They will become irritated if they were to sit for a longer period. They love experimenting, exploring and executing tasks (Ldpride.net, 2008).

\subsection{Employee Creativity}

In the service field of $21^{\text {st }}$ century, it is necessary to fulfil the demands of customers and highlight their complaints by resolving efficiently to ensure customer satisfaction. Thus, hiring innovative and creative 
employees has become important aspect of managers to increase employee creativity to profit from their creativity skills. Hence, organizations innovativeness can be increased by increasing employee creativity (Yao, Yang, Dong \& Wang, 2010). Employees can use intellectual abilities to bring positive changes to attain a specific goal by using their knowledge, skills and creativity to empower these changes (Alirezaei \& Tavalaei, 2008).

Fisher, (2008) stated that employee performance is dynamic and changes over time and such changes can be permanent due to learning or temporary due to changes in affective state (Fisher \& Noble, 2004; Beal et al., 2005 ).The importance of creativity in organization is due to enhancement in efficiency of work and positive reaction toward opportunities (Unsworth, 2001). It also helps to adjust in certain environment, better growth and survival in the competent world. Some researchers also describe the level of creativity according to the work (Oldham \& Cummings, 1996).

\section{Rationale of the Study}

The aim of this study was to explore the relationship of cognitive styles and learning styles ad to explore the influence of learning styles on employee creativity. As these phenomena are studied separately because cognitive styles and learning styles relationship are often studied in the subject matter of psychology. Nevertheless, very little research work which have been conducted on the influence of learning styles on employee creativity. Therefore, to explore this phenomenon this study was conducted. There is no previous research evidence available where this phenomenon is collectively studied as cognitive styles, learning styles and employee creativity. Furthermore, the moderating effect of cognitive styles on learning styles and employee creativity was also studied.

\section{Objectives of the study}

1. To investigate the cognitive styles, learning styles and employee creativity among employees belonging to different sectors

2. To inspect if there are any demographic variations among these three variables

3. To explore moderating effect of cognitive styles on employee creativity and learning style

\subsection{Methodology Participants}

The participants consist of 450 employees. Data was collected from three different public and private sectors that are banking, insurance and telecommunication. 450 questionnaires were distributed in different organization and 150 questionnaire were distributed to each sector. Purposive sampling technique was used for the collection of data, which is a type of non-probability sampling.

\subsection{Instruments}

Three instruments were used to collect data.

\subsection{Cognitive Style Inventory}

This inventory was developed by Ancona, Kochan, Scully, Van Maanen, and Westney in 1997. It consists of thirty items. Each item has two parts. Each part is given scores in between the range of 5. The Cronbach's alpha value of scale is 0.742

\subsection{Learning Style Questionnaire}

Learning Style Questionnaire was developed by O Brein in 1985. It consists of thirty items. A 3-item scale designed to measure learning styles of employees. The three types of learning styles which are auditory, visual and kinesthetic. The Cronbach's alpha value of scale is is 0.805

\section{Employee Creativity Questionnaire}

Employee creativity questionnaire was adopted from the Tierney et al. in 1999.It consists of 10 statements and rated on a five-point Likert scale. Reliability The Cronbach's alpha value of scale is is 0.752

\subsection{Procedure}


A sample of 450 students was selected. Data was collected from the different sectors of Pakistan such as banks, insurance and telecommunication. 150 data were collected from each sector. Their age range was 25-60 years. For the purpose of data collection, purposive sampling technique was used. The employees were approached in their respective sectors. They were briefed about the nature and purpose of the research being carried out. Every participant took 20 to 25 minutes to fill the questionnaire. When the questionnaire filing was completed, scoring session was done according to the scale method. Frequency distribution, ANOVA, t-test, Mean and PLS analysis were applied for the analysis of data.

\section{Results}

Data from 450 adults was included with demographic variables used in this research data are age, gender and education, job duration and department. The totals, means and standard deviations for age, education, gender, job duration and departments were calculated. The results are presented by using descriptive statistics, by using one-way analysis of variance (ANOVA), and PLS analysis.

\section{Table: 1}

Descriptive statistics of respondents among different sector

\begin{tabular}{|c|c|c|c|c|}
\hline Dimension & Sectors & & & SD \\
\hline & Banks & 69 & 22.5712 & .90112 \\
\hline \multirow[t]{3}{*}{ Feeling } & Insurance & 75 & 20.4133 & .87137 \\
\hline & Telecommunication & 59 & 23.9051 & 1.00437 \\
\hline & $\begin{array}{l}\text { Total } \\
\text { Banks }\end{array}$ & $\begin{array}{c}203 \\
32\end{array}$ & $\begin{array}{l}21.4187 \\
21.1250\end{array}$ & $\begin{array}{l}.92117 \\
.75134\end{array}$ \\
\hline \multirow[t]{3}{*}{ Thinking } & Insurance & 30 & 22.98667 & .87428 \\
\hline & Telecommunication & 48 & 20.0092 & .81187 \\
\hline & $\begin{array}{l}\text { Total } \\
\text { Banks }\end{array}$ & $\begin{array}{c}110 \\
46\end{array}$ & $\begin{array}{l}21.0727 \\
23.9183\end{array}$ & $\begin{array}{c}.80945 \\
1.02717\end{array}$ \\
\hline \multirow[t]{2}{*}{ Sensing } & Insurance & 47 & 21.4043 & .99257 \\
\hline & $\begin{array}{c}\text { Telecommunication } \\
\text { Banks }\end{array}$ & $\begin{array}{l}61 \\
59\end{array}$ & $\begin{array}{l}20.1639 \\
23.5085\end{array}$ & $\begin{array}{l}.79959 \\
.87834\end{array}$ \\
\hline \multirow[t]{3}{*}{ Intuitive } & Insurance & 58 & 21.9207 & 1.02323 \\
\hline & Telecommunication & 53 & 20.0585 & 1.03950 \\
\hline & $\begin{array}{l}\text { Total } \\
\text { Banks }\end{array}$ & $\begin{array}{c}170 \\
34\end{array}$ & $\begin{array}{l}21.5000 \\
24.5588\end{array}$ & $\begin{array}{c}.98058 \\
3.20219\end{array}$ \\
\hline
\end{tabular}




\begin{tabular}{|c|c|c|c|c|}
\hline \multirow[t]{4}{*}{ Visual Learning Style } & Insurance & 33 & 16.3030 & 2.20064 \\
\hline & Telecommunication & 46 & 29.0870 & 3.60140 \\
\hline & Total & 113 & 19.6991 & 3.11931 \\
\hline & Banks & 66 & 20.1818 & 1.92081 \\
\hline \multirow[t]{4}{*}{ Auditory Learning Style } & Insurance & 50 & 20.2000 & 2.20389 \\
\hline & Telecommunication & 70 & 20.9714 & 1.94840 \\
\hline & Total & 186 & 20.4839 & 2.03543 \\
\hline & Banks & 106 & 26.5755 & 2.48020 \\
\hline \multirow[t]{4}{*}{ Kinesthetic Learning Style } & Insurance & 114 & 17.5000 & 3.02570 \\
\hline & Telecommunication & 87 & 22.1264 & 1.90351 \\
\hline & Total & 307 & 20.4202 & 2.55834 \\
\hline & Banks & 150 & 34.8333 & 2.31545 \\
\hline \multirow[t]{2}{*}{ Creativity } & Insurance & 150 & 29.7733 & 2.39448 \\
\hline & Telecommunication & 150 & 41.0867 & 3.05857 \\
\hline
\end{tabular}

Table 1 indicates the descriptive statistics of dimension of cognitive style, learning style and creativity among organization. The maximum value is $23.90(\mathrm{M}=23.9051, \mathrm{SD}=1.00437)$ which is approximately 24 in feeling dimension of cognitive style in telecommunication sector. The maximum value is 22.98 $(\mathrm{M}=22.98667, \mathrm{SD}=0.87428)$ which is approximately 23 in thinking dimension of cognitive style in insurance sector. The maximum value is $23.91(\mathrm{M}=23.9183, \mathrm{SD}=1.02717)$ which is approximately 24 in thinking dimension of cognitive style in banking sector. The maximum value is 23.50 ( $\mathrm{M}=23.5085$, $\mathrm{SD}=0.87834$ ) which is approximately 24 in intuitive dimension of cognitive style in banking sector. The maximum value is $29.08(\mathrm{M}=29.0870, \mathrm{SD}=3.60140)$ which is approximately 29 in visual learning style in banking sector. The maximum value is $20.97(\mathrm{M}=20.9714, \mathrm{SD}=1.94840)$ which is approximately 21 in auditory learning style in telecommunication sector. The maximum value is 26.57 ( $M=26.5755$, $\mathrm{SD}=2.48020$ ) which is approximately 27 in kinesthetic learning style in banking sector. The maximum value is $41.08(\mathrm{M}=41.0867, \mathrm{SD}=3.05857)$ which is approximately 41 in employee creativity in telecommunication sector. 
Table: 2

One Way ANOVA Analysis of respondents in different sectors

\begin{tabular}{|c|c|c|c|c|c|c|}
\hline \multirow[t]{2}{*}{ Dimension } & & SS & Df & Mean square & F-statistics & p-value \\
\hline & BG & 6.496 & 2 & 3.248 & & \\
\hline \multirow[t]{3}{*}{ Feeling } & WG & 164.13 & 200 & 0.82065 & 3.957838 & $0.041^{*}$ \\
\hline & Total & 170.626 & 202 & & & \\
\hline & BG & 8.772 & 2 & 4.386 & 7.491332 & $0.009 * * *$ \\
\hline \multirow[t]{2}{*}{ Thinking } & WG & 62.646 & 107 & 0.585477 & & \\
\hline & $\begin{array}{c}\text { Total } \\
\text { BG }\end{array}$ & $\begin{array}{c}71.418 \\
7.952\end{array}$ & $\begin{array}{c}109 \\
2\end{array}$ & 3.976 & 4.874844 & $0.008^{* *}$ \\
\hline \multirow[t]{3}{*}{ Sensing } & WG & 123.158 & 151 & 0.815616 & & \\
\hline & Total & 131.11 & 153 & & & \\
\hline & BG & 13.91 & 2 & 6.955 & 7.81671 & $0.005 * * *$ \\
\hline \multirow[t]{3}{*}{ Intuitive } & WG & 148.59 & 167 & 0.88976 & & \\
\hline & Total & 162.5 & 169 & & & \\
\hline & BG & 112.766 & 2 & 56.383 & 6.348111 & $0.025 * *$ \\
\hline \multirow[t]{3}{*}{ Visual } & WG & 977.004 & 110 & 8.881855 & & \\
\hline & Total & 1089.77 & 112 & & & \\
\hline & BG & 26.691 & 2 & 13.345 & 3.301 & $0.039 *$ \\
\hline \multirow[t]{3}{*}{ Auditory } & WG & 739.761 & 183 & 4.042 & & \\
\hline & Total & 766.452 & 185 & & & \\
\hline & BG & 110.789 & 2 & 55.3945 & 10.57781 & $0.000 * * *$ \\
\hline \multirow[t]{3}{*}{ Kinesthetic } & WG & 1592.01 & 304 & 5.236859 & & \\
\hline & Total & 1702.794 & 306 & & & \\
\hline & BG & 98.298 & 2 & 49.149 & 8.299812 & $0.002 * * *$ \\
\hline
\end{tabular}




$\begin{array}{lllll}\text { Creativity } & \text { WG } & 2647 & 447 & 5.9217\end{array}$

Total $\quad 2745.298 \quad 449$

Note: $* \mathrm{p}<0.05, * * \mathrm{p}<0.01, * * * \mathrm{p}<0.001, \mathrm{SS}=$ sum of squares, $\mathrm{BG}=$ between groups, $\mathrm{WG}=$ within groups

Table 2 displays the analysis of variance (ANOVA) of feeling dimension of cognitive style among organizations. It clearly indicates that the result is significant because p-value is less than the nominal level of significance $(\alpha=0.05)$. It means feeling dimension of cognitive style among organization is significant. Hence, feeling dimension of cognitive style exists among organization. The analysis of variance (ANOVA) of thinking dimension of cognitive style among clearly indicates that the result is significant because $p$-value is less than the nominal level of significance $(\alpha=0.001)$. It means thinking dimension of cognitive style among organization is significant. Hence, thinking dimension of cognitive style exists among organization. The analysis of variance (ANOVA) of sensing dimension of cognitive style clearly indicates that the result is significant because p-value is less than the nominal level of significance $(\alpha=0.01)$. It means sensing dimension of cognitive style among organization is significant. Hence, sensing dimension of cognitive style exists among organization. The analysis of variance (ANOVA) of intuitive dimension of cognitive style clearly indicates that the result is significant because $p$-value is less than the nominal level of significance $(\alpha=0.001)$. It means intuitive dimension of cognitive style among organization is significant. Hence, intuitive dimension of cognitive style exists among organization. The analysis of variance (ANOVA) of visual learning style clearly indicates that the result is significant because $p$-value is less than the nominal level of significance $(\alpha=0.01)$. It means visual learning style among organization is significant. Hence, visual learning style exists among organization. The analysis of variance (ANOVA) of auditory learning style clearly indicates that the result is significant because $p$-value is less than the nominal level of significance $(\alpha=0.05)$. It means auditory learning style among organization is significant. Hence, auditory learning style exists among organization. The analysis of variance (ANOVA) of kinesthetic learning style clearly indicates that the result is significant because $p$-value is less than the nominal level of significance $(\alpha=0.001)$. It means kinesthetic learning style among organization is significant. Hence, kinesthetic learning style exists among organization. The analysis of variance (ANOVA) of employee creativity clearly indicates that the result is significant because $p$-value is less than the nominal level of significance $(\alpha=0.001)$. It means employee creativity among organization is significant. Hence, employee creativity exists among organization.

Table: 3 Path Coefficients of different variables

\begin{tabular}{lllll}
\hline Hypothesis & Path Coefficient & t-Statistics & p-value & Result \\
\hline CS $\rightarrow$ EC & 0.229 & 3.09 & 0.003 & Supported \\
LS $\rightarrow$ CS & 0.248 & 3.265 & 0.001 & Supported \\
LS $\rightarrow$ EC & 0.279 & 4.399 & 0.000 & Supported \\
\hline
\end{tabular}

Note: CS="cognitive styles", EC="Employee Creativity", LS=" Learning Styles"

The bootstrap re-sampling method (with 450 re samples) was used to determine the significance of the path coefficients and to test hypothesis. The partial least square structural equation modeling (PLS-SEM) results are shown in Figure 1. It shows that the direct association occurs between learning styles and employee creativity. In addition, we also analyze the coefficient of determination $\left(R^{2}\right)$ and value of $R^{2}$ for employee creativity is 0.329 and $R^{2}$ for cognitive styles is 0.157 . The significant result has been obtained 
because the $p$ value is less than the level of significance (0.01). This model also show the moderation in which cognitive styles are the moderator between learning styles and employee creativity including the direct association between participants' learning styles and their employee creativity and the indirect association of these perceptions through their association with cognitive styles estimated using PLS-SEM. In the link between learning styles and employee creativity there is $(\beta=0.279, t=4.3399, p<0.01)$. In the same way Figure 1 also show that learning styles and cognitive styles relationship has $(\beta=0.248$, $t=3.265, p<0.01)$. The link between cognitive styles and employee creativity has values as $(\beta=$ $0.229, t=3.09, p<0.01$ ). It clearly indicates that there is significant moderation between learning styles and employee creativity.

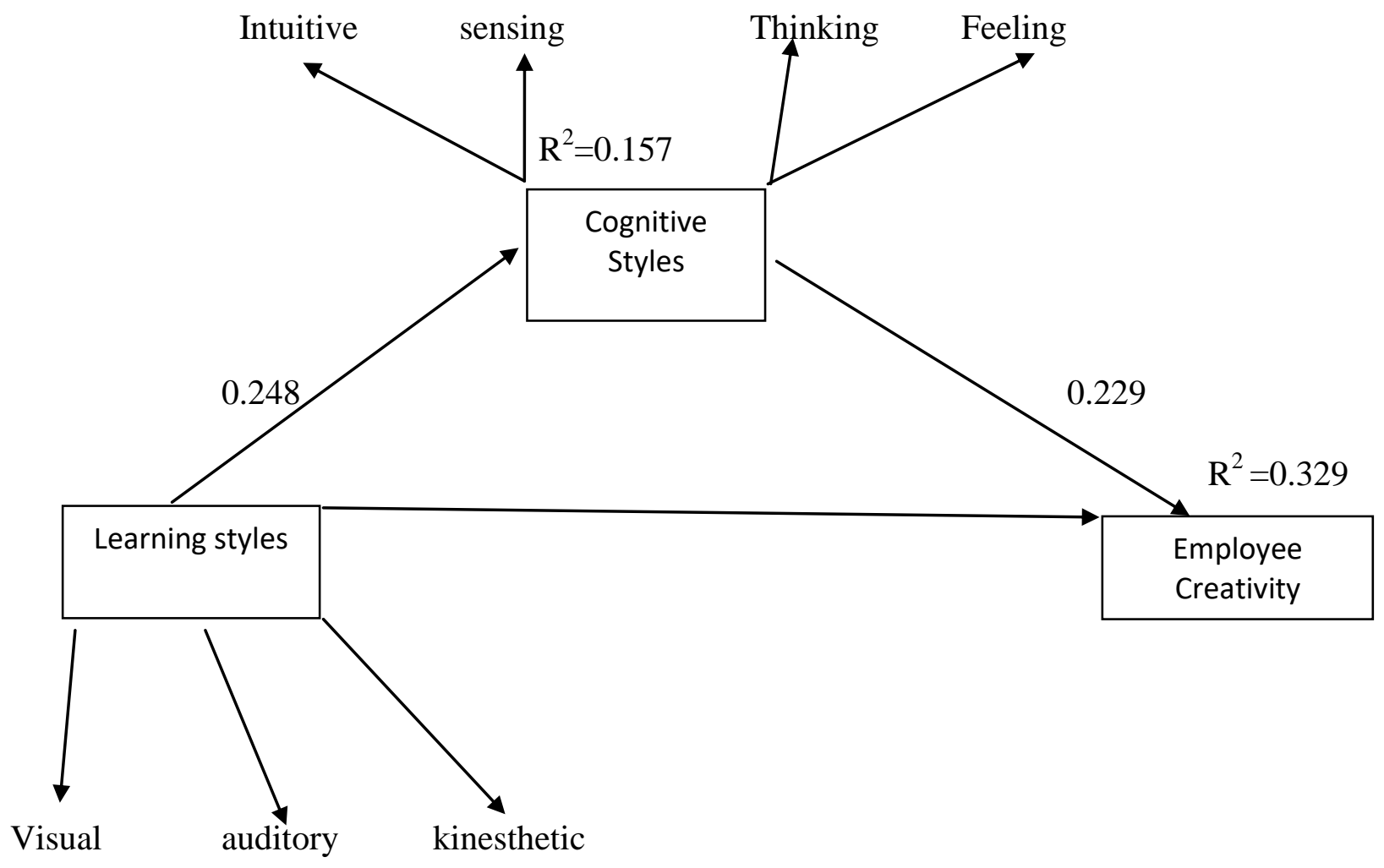

Figure 1: PLS Analysis

\section{Discussion}

This study was conducted to study the moderating role of cognitive styles between learning styles and employee creativity among employees. The data is collected from different departments so the descriptive statistics of the variables of the study was also discussed and their significant difference was also studied with demographic variables like age, gender, job duration and department.

First assumption of the study states that cognitive styles will vary among employees of different sectors. The results show that out of eight dimensions of the cognitive styles, four dimensions are prominent in our findings, which are feeling, thinking, sensing and intuitive. Results in table 1 shows that feeling dimension is far greater in telecommunication sector as compared to the other sectors. This result may be due to the possibility that the person itself value them a lot and according to Myers-Briggs cognitive processing type these kind of individuals are over committed, they have their own personal perspective to generate new ideas, they love when people are around and in telecommunication sector their job requirement is to outgoing and connected to the world. Thus, it shows a significant relationship among organizations as $\mathrm{p}>0.05$. Results in table 1 also shows that thinking dimensions are prominent in insurance sector among employees belonging to different sectors. This result may be due to the possibility 
that the person working in insurance sector make difficult decisions at times and they are continuously tried to enhanced their self and come up with innovative ideas. According to Myers-Briggs cognitive processing type these individuals are they are analytical thinker, they are impersonal and detached, they have tough minded and task oriented, they have clear criteria of right and wrong and they made judgments that are intellectually true. This it shows a significant relationship among employees belonging to different sectors as p>0.001 as this is supported by our previous finding. (Claxton et al., 1996) Results in table 1 shows that sensing dimensions are prominent in banking sector among employees belonging to different sectors. This result may be due to the possibility that the person working in banking sector is practical and empirical in their thinking because they process information on the basis of their physical features. According to Myers-Briggs cognitive processing type these individuals are they are practical thinker, they are aware of their surroundings, they are realist and concrete, they work through their senses, love to live in present and rely on factual knowledge. This it shows a significant relationship among employees belonging to different sectors as p>0.01. Results in table 1 shows that intuitive dimensions are prominent in banking sector among employees belonging to different sectors. This result may be due to the possibility that the person working in banking sector has a job requirement to generate new ideas because they process information based on patterns and their impressions. According to Myers-Briggs cognitive processing type these individuals are they are future forecast and they work on the basis of future demands, they are theoretical and abstract in their thinking, they are idealist, they have hidden abilities to deal with the unwanted circumstances and they think beforehand the possibilities of a particular outcome, love to live in future and rely on possibilities which is the demand of the higher professionals working in banking sector. This it shows a significant relationship among employees belonging to different sectors as $\mathrm{p}>0.001$.

It was also assumed that learning styles will vary among employees of different sectors. The results show that there are three different styles of learning styles during the process of learning which are visual, auditory and kinesthetic. Learning styles determines the way we gather, store and retrieve the information. Hypothesis 2a states that Visual style of learning styles will be varying among employees in different sectors. The findings support this hypothesis. The results were significant at $p>0.01$. Results in table 1 shows that visual learning style is far dominant in banking sector as compared to the other sectors. This result may be due to the possibility that the person tried to remain in the front row and according to Ldpride.net (2008) type these kind of individuals are position holders, they love to manage events as this type of learning style is the demand and requirement of higher personnel because they have tours to foreign companies meet foreign delegates so they need to be in the front row to make their place in the market.

Hypothesis of the study states that auditory learning styles will be varying among employees in different sectors. The findings support this hypothesis. The results were significant at $\mathrm{p}>0.05$. Results in table 1 shows that auditory learning style is far dominant in telecommunication sector as compared to the other sectors. This result may be due to the possibility that there is a lot of changing in the markets takes place, competition is so enhanced that new products like mobile phones, machines, Ac, new packages of the different telecommunication companies like Jazz, U-fone and Telenor is introduced on the daily basis their policies change from day to day so there is a requirement of a person to be a part of organization that he should active listener and if he is an active listener than his works have that efficiently which the organization is demanding. And according to Ldpride.net (2008) type these kinds of individuals can easily absorb new information and process then in a far greater speed. The usually retain information for a longer time period.

Hypothesis 1 states that kinesthetic learning styles will be varying among employees in different sectors. The findings support this hypothesis. The results were significant at $\mathrm{p}>0.001$. Results in table 1 shows that kinesthetic learning style is far dominant in banking sector as compared to the other sectors. This result may be due to the possibility that the person tried experimenting, exploring and executing tasks and according to Ldpride.net (2008) type these kind of individuals explore new possibilities as this type of 
learning style is the demand and requirement of higher personnel because for a person to become successful he must explore new opportunities and avail that opportunities to become successful in the future and attained the set benchmarks.

Assumption of this investigate states that employee creativity will vary among employees of different sectors. The findings support this hypothesis. The results were significant at $p>0.001$. Results in table 1 shows that employee creativity is dominant in telecommunication sector as compared to the other sectors. This result may be due to the possibility that a person needs a lot of hard work and potentials to stay in the organization which demanded a lot of creativity from the employees as there is a lot of changing in the markets takes place, competition is so enhanced that new products like mobile phones, machines, Ac, new packages of the different telecommunication companies like Jazz, U-fone and Telenor is introduced on the daily basis their policies change from day to day. It brings efficiency in the employee's work. As organization preferred those individuals subsequently who are beneficial to their organization in the long term. This brings about the fact that employee creativity enhanced the individual performance to manifold and hence increases the employee's demand in a particular organization.

Another hypothesis of the study states that cognitive styles will have moderating effect on learning styles and employee creativity. The findings support this hypothesis. The results were significant at $\mathrm{p}>0.01$. Present study focused to explore the moderating role of cognitive styles, purpose of the study was to find how cognitive styles influences the relationship between learning styles and employee creativity among employees belonging to different sectors. Results supported the hypothesis and results were significant at $p<.01$, moderator variable produced these results are depicted in table 3 and the visual representation is presented on figure 1.

\section{Conclusion}

Feeling dimension is dominant in the telecommunication sector, thinking dimension is dominant in insurance sector, sensing dimension is dominant in banking sector and intuitive dimension is dominant in banking sector. Three learning styles are mainly used in the study where visual learning style is dominant in banking sector; auditory learning style is dominant in telecommunication sector and kinesthetic learning style is dominant in banking sector.

\section{References}

Alirezaei A, Tavalaei R. (2008). Innovation in the organizations. Journal of Managing Human Resource Oil, 2(3), 69-70.

Ancona, D. G. (1999). Managing for the future: organizational behavior \& processes. Thomson SouthWestern.

Ausburn, L. J., \& Ausburn, F. B. (1978). Cognitive styles: Some information and implications for instructional design. Educational Communication and Technology, 26(4), 337-354.

Beal, D. J., Weiss, H. M., Barros, E., \& MacDaniel, S. M. (2005). An episodic process model of affective influences on performance. Journal of Applied Psychology, 90(6), 1054-1068.

Chen, C. C., \& Lin, P. H. (2016). Development and evaluation of a context-aware ubiquitous learning environment for astronomy education. Interactive Learning Environments, 24(3), 644-661.

Dörnyei, Z. (2005). The Psychology of the Language Learner: Individual Differences in Second Language Acquisition. Mahwah, NJ: Lawrence Erlbaum.

Fisher, C. D. (2008). What if we took within-person performance variability seriously? Industrial and Organizational Psychology, 1(2), 185-189.

Fisher, C. D., \& Noble, C. S. (2004). A within-person examination of correlates of performance and emotions while working. Human Performance, 17(2), 145-168.

Goldstein, K.M, Blackman, S. (1978). Cognitive Styles: Five Approaches and Relevant Research. New York: Wiley \& Sons.

Hwang, G. J., Kuo, F. R., Yin, P. Y., \& Chuang, K. H. (2010). A Heuristic algorithm for 
planning personalized learning paths for context-aware ubiquitous learning. Computers \& Education, 54(2), 404-415.

Jung, C.G. (1923). Psychological types. Princeton, NJ: Princeton University Press.

Ldpride.net (2008). Understanding Your Learning Styles. Retrieved July 21, 2013, from http://www.roe11.k12.il.us/GES\%20Stuff/Day\%203/Understanding\%20Your\%20Learn ng\%20Styles.pdf.

Lucas, M. R. D., \& Corpuz, B. B. (2007). Facilitating learning: a Metacognitive Process. Lorimar Publishing.

O'Brien, T. P. (1990). Construct validation of the Gregor delineator: An application of Lisrel. Educational and Psychological Measurement, 50(2), 631-636.

Oxford, R. L. (2011). Teaching and Researching Language Learning Strategies. Harlow: Pearson Longman.

Palmquist, R.A. \& Kim, K-S. (2000). Cognitive Style and On-line Database Search Experience as

Predictors of Web Search Performance. Journal of the American Society for Information Science, $51(6), 558-566$

Pask, G. (1976) Styles and Strategies of Learning. British Journal of Educational Psychology, 46(2), 128-148.

Ridding, R. \& Cheema, I. (1991). Cognitive Styles: An Overview and Integration. Educational Psychology, 11(3), $193-216$.

Reid, J. M.(ed.). 1995). Learning Styles in the ESL/EFL Classroom. Boston, MA: Heinle \& Heinle.

Roberts, M.J. \& Newton, E.J. (2001), Understanding Strategy Selection. International Journal of Human-

Computer Studies, 54(1), 137 - 154.

Sternberg, R. J. and E. L. Grigorenko.1997. 'Are cognitive styles still in style?' American Psychologist, 52(7), 700-12.

Unsworth, K. (2001). Unpacking creativity. Academy of Management Review, 26(2), 289-297.

Unsworth, L. (2005). Teaching multiliteracies across the curriculum: Changing contexts of text and image in classroom practice. Buckingham, UK: Open University Press.

Oldham GR, Cummings A (1996). Employee creativity: Personal and contextual factors at work. Journal of Academic Management, 39(3), 607-634.

Tierney, P., Farmer, S.M. and Graen, G.B. (1999) An examination of leadership and employee creativity: the relevance of traits and relationships. Personnel Psychology, 52(3), 591-620.

Yao, X., Yang, Q., Dong, N. \& Wang, L. (2010). Moderating effect of Zhong Yong on the

relationship between creativity and innovation behavior. Asian Journal of Social Psychology, 13(1). 53-57. 